\title{
Formulating Popular Policies for Peat Restoration Based on Livelihoods of Local Farmers
}

\author{
Elisa Wildayana $^{1} \&$ M. Edi Armanto ${ }^{1}$ \\ ${ }^{1}$ Faculty of Agriculture, Universitas Sriwijaya, South Sumatra, Indonesia \\ Correspondence: Elisa Wildayana, Jln. Palembang-Prabumulih KM 32, Indralaya Campus (30662), South \\ Sumatra, Indonesia. E-mail: ewildayana@unsri.ac.id
}

Received: February 4, 2018

Accepted: March 14, $2018 \quad$ Online Published: May 30, 2018

doi:10.5539/jsd.v11n3p85

URL: https://doi.org/10.5539/jsd.v11n3p85

\begin{abstract}
Important peatland issues developed were how to restore peatlands and followed by increasing rural livelihoods. This research aimed to analyze how peatlands can be utilized to alleviate poverty? and how to integrate peatland restoration with poverty alleviation. This research has been conducted in peatlands of OKI district, South Sumatra Indonesia in 2017. Data about bio geophysical aspects of peatlands, social, economic and political institutions of farmers were surveyed in the fields, performed in qualitative and quantitative approach, and analyzed in forms of tables and descriptions. Important themes have been discussed in formulating popular policies for peat restoration based on livelihoods of local farmers, among others poor groups; characteristics of farmers from the socio-political aspect; concept of peatland restoration and other lessons-learnt; compatibility of peat-based poverty alleviation; and need to improve policy making. The chronic poor sites tend to overlap with peatland degradation; it is more important to cultivate peatlands to prevent farmers from falling into deeper poverty than to reduce farmers out of poverty, and the intrinsic quality of peatlands and their contents tends to conflict with poverty alleviation goals, but there are some possible trends to minimize peatlands degradation and to alleviate poverty simultaneously. The best approach is to apply the 'win-lose' or 'lose-win' approach, even though we are not able to avoid peatland degradation at a zero level, but at least it can be inhibited. Cooperation between investors and farmers in managing peatlands is needed, so that the peatland resources are not completely degraded.
\end{abstract}

Key words: livelihoods, poverty, popular policies, peatlands, restoration

\section{Introduction}

The government as a regulator in 2014 appeared Government Regulation Nr 71/2014 on the protection and management of peatland ecosystems, but farmers do not pay serious attention to the regulation (Armanto et al., 2017b). Land clearing by farmers living on surrounding peatlands is often done without good planning, which leads to inequality in land use, for example land clearing by burning and illegal logging (Armanto \& Wildayana, 2016; Ningsih et al., 2017).

As a result, peatlands are degraded due to peat subsidence, causing the area around the peatland dome is subjected to floods. This is then exacerbated by the shrinking of economic resources that can be utilized by communities in the peatlands (Adriani \& Wildayana, 2015). This degradation will make productivity of farmers decline because of the difficulty of obtaining economic resources. This inevitably makes farmers vulnerable to poverty (Adriani et al., 2018; Zahri et al., 2018). Poverty vulnerability causes farmers to stay pushed back to clear land without good planning (Wildayana et al., 2017; Lu, 2017). This cycle is used by the community in the use of peatlands. Peat utilization often ignores land security rules where logging and land clearing are done by burning. This causes the fire easily to spread to other areas and make forest fires become massive (Wildayana, 2017; Udoh et al., 2017).

Peat degradation will significantly affect the global climate and contribute to the biodiversity loss, reduced supply of fresh water, floods, drought, and land and water pollution (Sarno et al., 2017). These impact components will all directly affect economic activity, directly influence livelihood sources, daily life farmers strongly depending to peatlands (Pangerungan et al., 2017; Wildayana, 2018; Wildayana \& Armanto, 2018).

Two areas of peatlands can be utilized, namely forest and non-forest areas. Local communities are only allowed 
to work on smallholder plantations and production forests, while forests that are burdened with rights are still discussed by the government, especially in Agrarian Reform. The government declares to partner with the community in managing forest resources that fall within customary forest areas. Various rural patterns of livelihoods commonly found in the research areas are hunting and gathering; sonor system (slash and burn agriculture); and permanent agriculture in the broad sense (plantation, forestry and others). In line with increasing oil palm plantation and HTI (Industrial Plantation Forest) as well as degradation of peatlands, various rural patterns of livelihoods are declining, farmers are largely concentrated in the works of oil palm plantation and HTI. Some farmers who do not get jobs on oil palm plantations and HTI, they still do sonor system to meet their own needs. Such conditions accelerates the degradation of peatlands affecting not only the large companies, but also for farmers themselves, such as uncontrolled wildfires threats, floods, drought, land sliding, soil acidity and others. Thus the impact is increasing amount of poor farmers.

Two important issues in peatlands are poverty and peatlands degradation. In areas covered by peatlands, it has a higher rate of poverty (about $15.20 \%$ ) compared to the national poverty rate of $13.33 \%$ of the total population of Indonesia. The problem of poverty is not a new problem (Mugisha et al., 2017), but it has been around since thousands years ago. Poverty is exacerbated by the high gap income of farmers with groups of investors (Wildayana et al., 2016b;2016a), it is estimated that the income of investors reached more than 100 times higher than the income of farmers in general, despite the many efforts of the government in reducing poverty and income. This income gap, among others, is triggered by significant differences in education, opportunities in business or employment. This research aimed to analyze how peatlands can be utilized to alleviate poverty? and how to integrate peatland restoration with poverty alleviation. Significance and contribution of this research is to provide an overview and input to the knowledge and government that the management of peatlands requires the creation of a policy oriented to farmers in general. If this is not considered, peatland degradation affects anything and can even be completely destroyed.

\section{Materials and Methods}

This research has been conducted in peatlands of OKI (Ogan Komering Ilir) district, South Sumatra Indonesia (Figure 1) and carried out from July to December 2017. Field survey has been carried out to obtain data and facts from the existing conditions and look for factual information about bio geophysical aspects of peatlands, social, economic and political institutions of farmers. Rural patterns of peatland-based livelihoods were determined as research subjects and farmers from these livelihoods were taken as respondents. The respondents were determined by using stratified random sampling technique and comprehensively interviewed. Primary data were collected directly from the field with questionnaire and secondary data were taken from related institutions, NGO (non-governmental organizations) and oil palm companies. Data analysis conducted by this research was based on qualitative and quantitative approach, performed and analyzed in forms of tables and descriptions.

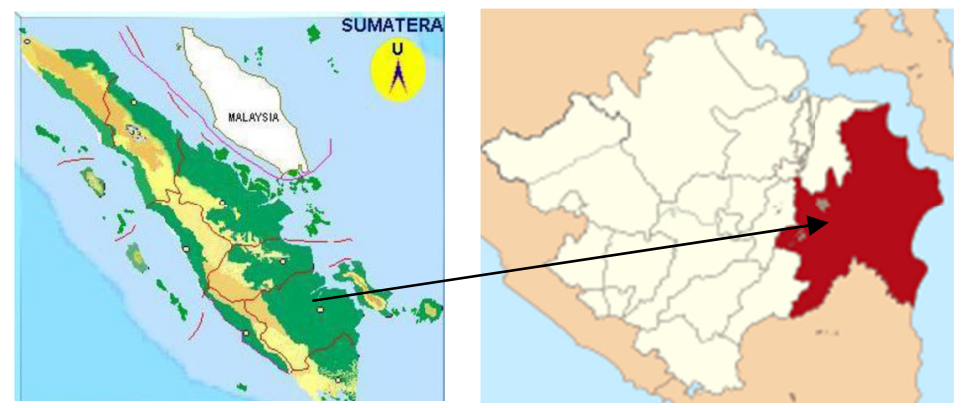

Figure 1. OKI District in South Sumatra Province, Indonesia (Source: Google website)

\section{Results and Discussion}

The question is whether peatlands can be utilized to improve employment and income effectively in order to alleviate poverty? If it is possible, then the increase in income of households is done without the peatland degradation that is difficult to restore? The important themes discussed are namely livelihood patterns of households on peatlands; poverty group in the research area; characterizing social-political farmers living in peatlands; concept of peatland restoration and other lessons-learnt; peatlands-based poverty alleviation compatibility; and the need to improve policy solutions. 


\subsection{Livelihood Patterns of Households on Peatlands}

Patterns of livelihoods have changed over time with respect to the use of peatlands. The basic typology of livelihoods is changing from hunting and gathering; to sonor system (slash and burn agriculture); and to permanent agriculture. Table 1 determines the following in relation to peatlands: livelihoods, types of peat utilization, peat density, how to use peatland resources (value versus exchange rate), and household dependence on peatland resources.

Three types of livelihoods patterns are performed on peatlands, i.e. hunting and gathering; sonor system; and permanent agriculture, which have different values and objectives on each attributes of the activities. These patterns of livelihoods are consistent with the findings of Imanudin et al (2018) and Armanto et al (2016). The attributes consist of 10 points which are the benefits, results, impacts and also the risks occurring in the peatlands.

Table 1. Rural patterns of peatland-based livelihoods

\begin{tabular}{|c|c|c|c|}
\hline \multirow[b]{2}{*}{ Attributes } & \multicolumn{3}{|c|}{ Rural patterns of livelihoods } \\
\hline & $\begin{array}{c}\text { Hunting \& } \\
\text { gathering }\end{array}$ & Sonor system & $\begin{array}{l}\text { Permanent } \\
\text { agriculture }\end{array}$ \\
\hline Patterns of peatland uses & $\begin{array}{l}\text { capturing \& } \\
\text { collecting }\end{array}$ & Shifting cultivation & $\begin{array}{l}\text { HTI \& oil palm } \\
\text { plantation }\end{array}$ \\
\hline Biodiversity density & high & low & medium \\
\hline Value uses for farmers & high & medium & low \\
\hline Exchange value of products & low & medium & high \\
\hline $\begin{array}{l}\text { Sharing product income to total } \\
\text { income }\end{array}$ & high & medium & low \\
\hline Welfare of farmers & low & medium & high \\
\hline Fire risk & low & high & medium \\
\hline Flood risk & low & high & high \\
\hline Drought risk & low & high & medium \\
\hline Peatland sustainability & high & very low & medium \\
\hline
\end{tabular}

Note : HTI (Industrial Plantation Forest)

Source: Field survey results (2017).

The hunting and gathering pattern belongs to the first community pattern, and is a very old agricultural activity, where farmers only use peatlands as hunting places to get food sources. The pattern of sonor systems is often done for mobile farming, where after harvesting time they will leave or abandoned, then they do sonor system on the other land. It is in line with Armanto et al (2017a) found that peatland degradation is mostly influenced by human intervention.

The permanent pattern of agriculture is the activity carried out on peatlands running for a long time where peatlands are usually used as HTI (Industrial Plantation Forest) or oil palm plantation. HTI and oil palm plantation is done in the long term because the oil palm itself takes five years to produce TBS (Fresh Fruit Bunches) and oil palm plant cycles can reach 25-30 years.

The biodiversity density is certainly strongly influenced by the activities or processing performed on peatlands. In the hunting and gathering, the density of biodiversity is high because peatlands lack of human intervention and farmers hunt for fauna and flora only. Then for the pattern of sonor system gives more impact of biodiversity density, which is worse than permanent agriculture pattern. This is because to perform the activities of the sonor system, farmers do land clearing by burning, thus damaging biodiversity density. Sarno et al (2017) also states that the existence and degradation of peatlands is associated with local agricultural activities.

The various resources that can be obtained in peatlands have a use value and exchange value in which both values are influenced by the product resulting from the livelihoods pattern performed in peatlands. For the 
highest use value is the product resulting from the pattern of livelihoods hunting and gathering. This is because the community can directly use it without having to do the exchange process. But for exchange value, hunting and gathering has the lowest value because the resources that can be obtained directly in peatlands are resources that usually have no high selling value such as purun plant (raw materials for making mats). Armanto et al (2013) and Widayana \& Armanto (2018) concluded that it is in line with conditions in the research area.

The highest exchange value is the product produced by the permanent agriculture livelihoods pattern, where peatlands are processed into palm oil and wood products for pulp and papers. Both of these products (palm oil and woods) have a high selling value because it is the raw material of various industries. However, the use value of permanent agriculture pattern is low because palm oil product cannot be taken directly used because it requires processing and a minimum of five years to produce. Contribution to welfare, permanent pattern of agriculture gives high contribution because of marketing of product status which resulted in increased income.

Risks that can occur in peatlands caused by livelihoods pattern activities, such as forest and land fires, floods and drought. The pattern of hunting and gathering has only a small chance of causing the risks to occur. While the pattern of sonor system and permanent agriculture has a high probability that risks occur. Sonor system pattern is very possible threat of land fires occur, this is because the sonor system does burning for land clearing, then after the harvest used land left alone. Lands were left and sensitively vulnerable to land fires. The permanent pattern of agriculture also improves the possibility of flood and drought threats. Peatlands that have been converted into plantation areas have changed the water absorption system because peatlands are no longer able to absorb water, so there may be flood and drought threats. Junedi et al (2017) stated that the change of nature of peatland caused conversion of peatland to agricultural activity in the broad sense.

The highest sustainability of peatlands is on hunting and gathering patterns. This is because in this pattern peatlands are not intensively disturbed, so the peatlands still have the original ability to recover themselves. However, the sonor system causes peatlands to no longer be used or even destroyed due to various activities carried out such as forest burning, resulting in peatlands losing their original functions.

\subsection{Characterizing Social-Political Farmers Living in Peatlands}

Most households as the research subject are farmers moving and/or farmers living in peatlands (i.e. hunting and gathering categories, and sonor systems). However, there are other livelihoods patterns found that are relevant and not described in this typology. Among them are unattached farming and grazing (small forest), small farmers focusing on tree planting or agro forestry for timber and firewood, or timber mill workers, small-scale loggers, timber collectors and others. Some of them live far from the peatlands, but to some extent they still depend on peatlands resources.

The farmers who live in the peatlands area fall into four broad categories (Table 2 and Figure 2). In general, the poor groups found in the peatlands area can be grouped into indigenous farmers, old settler migrants, new comers (transmigrants), and spontaneous comers. The division of this group is only to facilitate the understanding of the condition of rural society, however there is not clear delineation between each group.

Table 2. Farmers groups who occupy and inhabit the peatlands

\begin{tabular}{|c|c|c|}
\hline Farmers group & Origin & Description \\
\hline Indigenous farmers & $\begin{array}{l}\text { Native farmers who live in } \\
\text { their ancestral land }\end{array}$ & $\begin{array}{l}\text { Minority and live from generation to generation } \\
\text { in the peatlands }\end{array}$ \\
\hline $\begin{array}{l}\text { Old and settled } \\
\text { migrants }\end{array}$ & Derived from various tribes & $\begin{array}{l}\text { Farmers who have long lived in the peatlands, } \\
\text { but are not considered indigenous origin }\end{array}$ \\
\hline $\begin{array}{l}\text { New comers } \\
\text { (transmigrants) }\end{array}$ & $\begin{array}{l}\text { Javanese, Sundanese, } \\
\text { Balinese tribes }\end{array}$ & $\begin{array}{l}\text { Enter the peatlands territory through } \\
\text { transmigration programs by Government }\end{array}$ \\
\hline $\begin{array}{l}\text { Spontaneous } \\
\text { comers }\end{array}$ & $\begin{array}{l}\text { Investors, traders from } \\
\text { various tribes }\end{array}$ & $\begin{array}{l}\text { Doing estate agribusiness, HTI or demands of } \\
\text { work or businessman }\end{array}$ \\
\hline
\end{tabular}

Note: Field survey results (2017). 


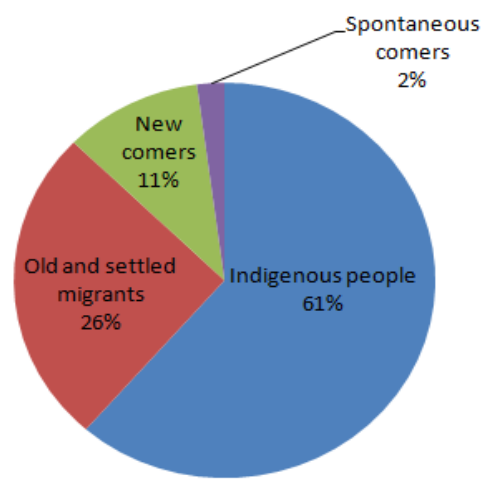

Note:

Indigenous farmers who living in their ancestral land;

Old and settled migrants (farmers) came from different tribes);

New comers (transmigrants from Java, Sunda and Bali tribes);

Spontaneous comers (investors and traders) coming from different tribes)

Figure 2. Percentage of farmers group in peatlands

Farmers depending and living in peatlands are powerless and have weakly political status compared to farmers living in the city. They compete with other farmers in terms of aspects, as follows: (1) national governments wishing to utilize original peatlands, which are often contradicted to customary regulations; (2) peatlands concession holders often collaborate with government officials (local or national legislative or military) to solidify their positions; (3) agro entrepreneurs (commercial farmers) find land to expand their business; (4) businessmen looking for high value products of peatlands; and (5) mining concession operators. Beside that developing infrastructure (roads, bridges or common facility) also compete with local farmers to gain peatlands.

The political weaknesses of peatlands dependent communities are stimulated by the long distance and bad infrastructure to the city center, where political investors that favor peatlands conversion tend to be established. Yosada et al (2017) found a similar phenomenon that local people living in areas far from urban areas have difficulty communicating and playing a political role in government. Not all contact with 'outsiders' puts peatlands in unfavorable positions. Some peatlands inhabitants work together with investor to form jointly alliances to utilize peatlands. There are also some destructive competition, which are not from attacks of outsiders, but it come from internal rural society. There are several logical relationships between the geography of poverty and peatlands summarized in Table 3 and Figure 3. This relationship is divided into groups of poverty comprising chronic poor, very poor, fairly poor and the temporary poor.

Table 3. The relationship between the geography of poverty and peatlands

\begin{tabular}{ll}
\hline \multicolumn{1}{c}{ Poverty } & \multicolumn{1}{c}{ Description } \\
\hline Chronic poor & Very strong dependence on peatlands, long before modern social change took place. \\
& It is primordial and should not be the result of contact with the modern economy \\
Very poor & Peatlands serve as a refuge or escape for the helpless and impoverished rural farmers \\
& who fled from conflict in the community \\
Poor & Occupy peatlands in "islands", where comparative stability is untouched by modern \\
& socioeconomic systems. \\
& Living in a remote area, reaching to markets and technology is slowed down \\
& (hampered); far distance from major roads, city center, ports, and projects of \\
& infrastructure. \\
& Has a low 'rent' rate due to ecological conditions, limited market access and services \\
Fairly poor & The existence of open-access or low barriers causes various projects that go to \\
& peatlands in favor of the poor. The existence of these projects makes it a means to \\
& survive and become an agent of development for rural limited-access farmers. \\
Temporary & New comers who have temporally failed to colonize the 'peatlands' villages for \\
poor & agribusiness; they do not belong to the poorest
\end{tabular}

Note: Field survey results (2017). 


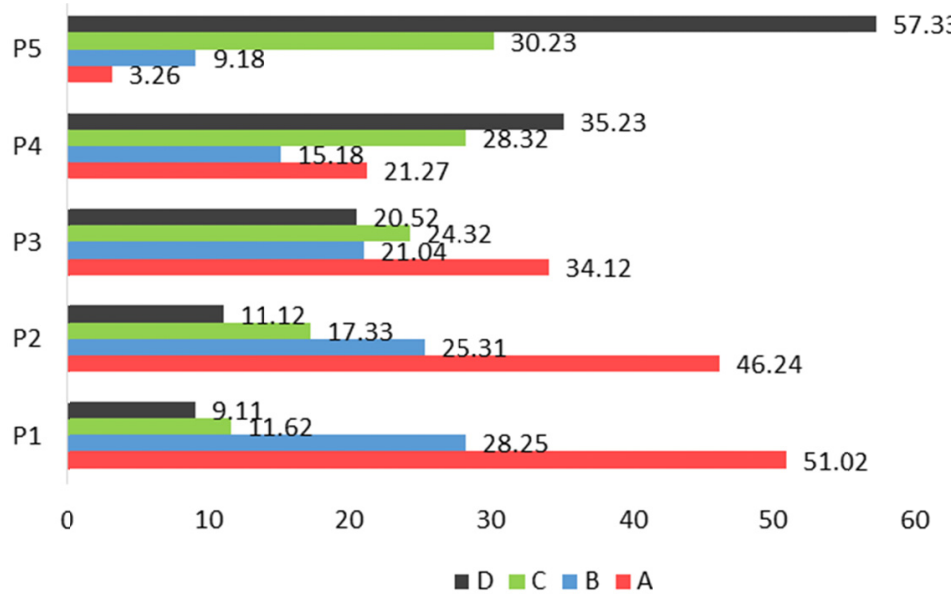

Note:

$\mathrm{A}=$ Indigenous people

$\mathrm{B}=$ Old migrants

$\mathrm{C}=$ New comers

$\mathrm{D}=$ Spontaneous comers

$\mathrm{P} 1=$ Chronic poor

$\mathrm{P} 2=$ Very poor

P3 = Poor

$\mathrm{P} 4=$ Fairly poor

P5 = Temporary poor

Figure 3. Percentage between the geography of poverty and peatlands (\%)

\section{Chronic Poor}

The chronic poor (the poorest) has income below the poverty line or have no income source and do not have access to various social services. This group is defined when the income is less than the rice exchange rate of $240 \mathrm{~kg} / \mathrm{capita} /$ year. The chronic poor is defined as farmers, who are not able to fulfill their fundamental needs, namely main food, housing, cloths, health as well as education and have no choice or access to other sources of livelihood other than those provided by nature. The farmers belonging to the chronic poor are indigenous farmers. They lived in the ancestral lands or ancestral lands and old and settled migrants who are immigrants from various ethnic groups who have also settled in peatland areas. Examples are local farmers whose main income comes from rice farming. The chronic poverty dependence on peatland is very high because this community has to believe peatlands as their main source of livelihood to support and support the socio-economic life of the community because the chronic poor has no choice but to utilize the existing natural resources.

\section{Very Poor}

The very poor is a community group, who is able to meet basic needs minimally because of income that is still below the poverty line such as food, clothing and housings. The very poor has income below the poverty line, but relatively has access to basic social services. Their income is only equivalent to a rice exchange rate of 240-360 kg/capita/year. The group of farmers belonging to the very poor category is indigenous farmers living in their ancestral land and migrant population who come from various tribes, but they have long lived in the area. The dependence of very poor communities is also very high on peatlands, where peatlands are used as a refuge or a run for poor rural communities to seek livelihoods from peatland resources.

\section{Poor}

The poor belongs to community group who has been able to meet basic needs, but still have limited access to social services. The poor are a community group characterized by a monotonous life because it has not been touched by modern civilization and is unwilling to accept change to improve its level of life despite attempts by outsiders to help. Their income is equivalent to a rice exchange rate of $360-480 \mathrm{~kg} / \mathrm{capita} /$ year. The group of farmers belonging to the poor is indigenous farmers, new comers (generally come from tribes of Java, Sunda and Bali), old and settled migrants. These groups occupy peatlands located in remote areas and very far from urban areas. The main economic activities of the community are still limited to agricultural activities, including crops, plantations, fisheries and livestock.

\section{Fairly Poor}

The fairly poor has income above the poverty line and their income is equivalent to a rice exchange rate of 480-960 kg/capita/year. This group has the ability to meet basic needs and gain access to social services at a minimum level. Groups belonging to the fairly poor category are dominated by spontaneous comers and new comers. They have opened minds and ready to accept changes coming from outside, such as governmental projects with the goals to improve the economy of the rural community. The existence of government and private projects is a means and access for local communities to continue to survive and become a driver of the economy of the farmers of the rural region. 


\section{Temporary Poor}

The temporary poor belongs to farmers, who are still vulnerable to changes in economic cycles from normal to economic crisis. Seasonal changes are found in cases of fisherman poverty and food crop agriculture, natural disasters or the impacts of certain policies that result in decreased incomes that lead to poverty. The temporary poor is categorized as having a relatively better life than the chronic poor and the poor. Their income is equal to or more than the rice exchange rate of $960 \mathrm{~kg} / \mathrm{capita} / \mathrm{year}$. Temporary poor communities, for example, are spontaneous comers, and new comers (transmigrants) that fail to enter and are unable to colonize villages adjacent to peatlands. The transmigrants or newcomers initially had the opportunity to gain access to the economy, but ultimately they failed and the inability to take over the peatlands in conducting farming activities to improve its stewardship. Therefore, the transmigrants are a group that is very vulnerable to natural poverty.

\subsection{Concepts of Peatland Restoration and other Lessons-Learnt}

The challenge to reconcile livelihoods and peatlands restoration is underdeveloped and mostly unfulfilled. Barati et al (2017) and Fobissie et al (2017) argued that it is necessary to humanity approach in the opinion unification between achieving reconciliation between the needs of livelihoods and sustainability application of natural resources. In the last few decades, the average rural incomes have increased, but natural peatlands have disappeared at high or severe degrees. The various solutions that have been tested have gone a long way from their original goals, although some positive impacts were identified in rural areas of peatlands; but there are many failures. Dzidza et al (2017) summarized the need for location-specific strategies for poverty alleviation and systematically implemented at the village level. Therefore, new creative approaches adaptive to the conditions of specific peatlands, such as payments for peatland services area guaranteed, however this approach is largely untested. For tropical peatlands not all of the above arguments can be applied. This is due to several factors, among others:

1) Peatlands in industrial countries are much different from tropical peatlands; therefore the method of restoration of industrialized countries is clearly different from tropical peatlands. Following and copying the ways in which advanced country restoration is an action that is not recommended and is naive.

2) To reach the peatlands turning point through the industrial state restoration program will have more impact on peatlands damage that will occur before the turning point is reached.

3) Peatlands restoration of industrialized countries is mostly on the basis of high fuel consumption, however in the research areas is because of extensification and intensification of agriculture and plantation.

4) Even though peatlands are closed then increased, it will not be the same peatlands. Much natural diversity will be automatically disappeared during the process.

Thus it has to be done some efforts to reconcile poverty alleviation and peatlands restoration intentionally and systematically at the site level. This should also be based on endogenous dynamics, regarding to exogenous international issues, regional, and national factors. Similar finding was also expressed by Limba et al (2017). These exogenous factors can be done through research and policy makers by government. The convergence of poverty alleviation and peatlands restoration is largely an unintentional artifact of high state dependence on oil revenues and low population.

\subsection{Compatibility between Peatlands with Poverty Alleviation}

Many action plans aim to produce 'win-win' results, where livelihoods improvements are tailored to the benefits of environmental protection. However, this action plan seldom determines 'win-win' results, nor does one win. We propose simple and fourfold typology to understand the results (Figure 4). Besides that, it needs technological innovation and business diversification to achieve sustainability of natural resources (Adriani et al., 2017; 2018; Zahri et al., 2018; Armanto et al., 2017b). Various activities carried out on peatlands can be done on condition that they have to pay attention to the original function of the peatlands themselves. So the benefits of these peatlands can be continued. Peatlands also need to be conserved to preserve the natural ecosystem.

\begin{tabular}{c|c|c|}
\multirow{1}{*}{ Welfare } & \multicolumn{2}{c}{ Peatland resources } \\
\cline { 2 - 3 } Positive (+) & Positive (+) & Negative (-) \\
\cline { 2 - 3 } & Win-Win & Win-Lose \\
\cline { 2 - 3 } Negative (-) & $(1)$ & Lose-Lose \\
\cline { 2 - 3 } & Lose-Win & $(4)$ \\
\cline { 2 - 3 } & $(3)$ &
\end{tabular}

Figure 4. Quadrant classification models of farmers welfare and peatland 
The relationship between peatland resource and welfare can be divided into 4 quadrants, namely Quadrant 1 (Win-Win); Quadrant 2 (Win-Lose); Quadrant 3 (Lose-Win); and Quadrant 4 (Lose-Lose). Activities undertaken in peatlands can be "Win" or "Lose" to communities and investors or governments. The four quadrants also have an impact on the level of peatland degradation (Table 4).

Table 4. Impacts of quadrant classification models on peatlands

\begin{tabular}{cll}
\hline Quadrant & \multicolumn{1}{c}{ Example } & \multicolumn{1}{c}{ Impacts to peatlands } \\
\hline Win-Win & Plantation/HTI - sonor system & Intensively degraded \\
Win-Lose & Plantation/HTI - employment & Moderately degraded \\
Lose-Win & No plantation - pineapple & Moderately degraded \\
Lose-Lose & Restoration - fallows & Slowly degraded \\
\hline
\end{tabular}

Source: Field survey results (2017).

Based on the quadrant analysis, it means that each activity undertaken by investors, government and society can have an impact on peatlands. The impact can determine the intensity of peatland degradation. The activities of the government and the community should be balanced with the sustainability of the peatlands.

\section{Win-Win Solution (Quadrant 1)}

Quadrant 1 (Win-Win) belongs to solution in which communities and private company (or governments) can conduct their respective business activities on peatlands. This solution is not probably applied, but there are important exceptions to the regulation, such as the agropolitan system (agriculture system by using urban facility); tree growth in the pastoral system; and multistate system based on the production of purun harvest (raw material for making mats). An example of a win-win solution here is plantation/HTI by the government or company and the sonor system by the community. Both activities are a win-win solution for both parties, but this gives the impact of high degradation of peatland because peatlands processed into plantation land that changes the function and ability of peatlands itself, while the sonor system by the community done by burning forest and land. This is certainly causing the degradation of the peatlands themselves as activities continue to be carried out, but no improvements are made.

\section{Win-Lose Solution (Quadrant 2)}

Quadrant 2 (Win-Lose) and Quadrant 3 (Lose-Win) are not much different where government or companies and local communities can conduct their business activities on peatlands. The impacts of both quadrants are the medium degradation of peatland; this is because peatlands are not massively cultivated. An example of a win-lose solution is a government or company doing business activities such as plantations and communities living around the peatlands are given the work opportunity in the plantation. In this situation peatlands are only transformed into plantations, so that the impact given to the land is the medium degradation of peatland. Not all of the peatlands are cleared or opened, so there are still some peatlands that are not touched or intact and kept as conservation areas.

\section{Lose-Win Solution (Quadrant 3)}

There are at least two situations that characterize the Lose-Win outcome: (1) situations in which the society is forcibly excluded from access to the resources of peatlands they rely on, for the purpose of restoration, causing welfare decline; and (2) situations where social conflicts make farmers unable to maintain their agricultural practices for fear of victimization, resulting in a decline in the welfare and recovery of peatlands naturally. An example of the Lose-Win solution is the government or the private company just support the local communities, while the community utilizes peatlands for paludiculture (resistant crops to fires), namely pineapple, purun for making mats and aloe vera. Peatlands are utilized for paludiculture farming by the local community, which have a medium degradation effect. In these circumstances, the company becomes a consumer or buyer of the agricultural products of paludiculture community.

\section{Lose-Lose Solution (Quadrant 4)}

Quadrant 4 (Lose-Lose) belongs to solution in which neither the government nor the company nor the community engages in business activities on the peatlands, but they restore the peatlands and do not damage the peatlands. In the 'Lose-Lose' solution, this Governments or companies or communities do not cultivate peatlands 
for their own business interests. This restoration activity needs a program of government with the aim to restore peatlands to return as before.

\section{Conclusions}

There are three points in relation to strategic poverty alleviation planning, firstly the chronic poor sites tend to overlap with peatlands, secondly it is more important to cultivate peatlands to prevent farmers from falling into deeper poverty than to alleviate farmers out of poverty, and thirdly an intrinsic quality of peatlands and the context of their use tends to conflict with poverty alleviation goals, but there is a new tendency that allows offsetting these undesirable qualities. The best solution is to apply 'win-lose' or 'lose-win' approaches to peatlands because peatlands degradation can be minimized, although we cannot avoid peatland degradation at the zero level, but at least it can be inhibited. Thus, it is needed to cooperate between investors with farmers in controlling peatlands, so peatlands are not destroyed altogether.

\section{Acknowledgment}

The author would like to express our gratitude to Sriwijaya University that has funded this research through the research scheme of "Penelitian Unggulan Profesi 2017". Thank you also to the Faculty of Agriculture Staff, Sriwijaya University who have shared experiences in this research with a constructive perspective. Thanks are directed to all students and local people who helped us with the field activities. Thanks are also for the anonymous reviewers for useful comments on this paper. We owe an inspiration to finalize the writing to the supporting staff for perfection of this paper (Sittah, Reszki and Fitri).

\section{References}

Adriani, D., \& Wildayana, E. (2015). Integrasi pertumbuhan ekonomi dan penciptaan kesempatan kerja sektor pertanian di Indonesia. Jurnal Sosiohumaniora, 18(3), 204-212. Retrieved from http://jurnal.unpad.ac.id/sosiohumaniora/article/view/8381

Adriani, D., Wildayana, E., Yulius, Alamsyah, I., \& Hakim, M. M. (2017). Technological innovation and business diversification: sustainability livelihoods improvement scenario of rice farmer household in sub-optimal land. Russian Journal of Agricultural and Socio-Economic Sciences, 9(69), 77-88. https://doi.org/10.18551/rjoas.2017-09.10

Adriani, D., Zahri, I., Wildayana, E., Maryadi, Hamzah, M., \& Yulius. (2018). Farmer's welfare in Telang's integrated independent city: lesson learned from migrant and local farmers in tidal land, South Sumatera. IOP Conf. Series: Earth and Environmental Science, 122, 1-7. Retrieved from https://iopscience.iop.org/issue/1755-1315/122/1

Armanto, M. E., \& Wildayana, E. (2016). Land degradation analysis by landscape balance in lebak swamp Jakabaring South Sumatra. Journal of Wetlands Environmental Managements, 4(1), 1-6. https://dx.doi.org/10.20527/jwem.04.01.01

Armanto, M. E., Adzemi, M. A., Wildayana, E., \& Imanudin, M. S. (2013). Land evaluation for paddy cultivation in the reclaimed tidal lowland in Delta Saleh, South Sumatra, Indonesia. Journal of Sustainability Science and Management, 8(1), 32-42.

Armanto, M. E., Imanudin, M. S., Wildayana, E., Junedi, H., \& Zuhdi, M. (2016). Managing actual problems of peatsoils associated with soil acidity. Sriwijaya Journal of Environment, 1(3), 58-63. https://dx.doi.org/10.22135/sje.2016.1.3.53-58

Armanto, M. E., Susanto, R. H., \& Wildayana, E. (2017). Functions of lebak swamp before and after landfills in Jakabaring South Sumatra. Sriwijaya Journal of Environment, 2(1), 1-7. https://dx.doi.org/10.22135/sje.2017.2.1.1-7

Armanto, M. E., Wildayana, E., Imanudin, M. S., Junedi, H., \& Zuhdi, H. (2017). Selected properties of peat degradation on different land uses and the sustainable management. Journal of Wetlands Environmental Managements, 5(2), 14-22. http://dx.doi.org/10.20527/jwem.v5i2.108

Barati, J., Soltani, S., Froogh-Zadeh, S., \& Razaghian, F. (2017). The role of human capital factors on poverty in informal settlement: Informal settlement of Sheikh-Hasan, Mashhad City, Iran. Journal of Sustainable Development, 10(4), 22-30. https://doi.org/10.5539/jsd.v10n4p22

Dzidza, P. M., Jackson, I., Normanyo, A. K., \& Walsh, M. (2017). The effects of poverty reduction strategies on artisanal fishing in Ghana: The Case of Keta Municipality. Journal of Sustainable Development, 10(3), 68-80. https://doi.org/10.5539/jsd.v10n3p68 
Fobissie, K., Etongo, D., \& Kanninen, M. (2017). An integrated approach to capacity development in forestry and climate change in West Africa. Journal of Sustainable Development, 10(5), 35-43. https://doi.org/10.5539/jsd.v10n5p35

Imanudin, M. S., Wildayana, E., \& Armanto, M. E. (2018). Option for Land and Water Management to Prevent Fire in Peat Land Areas of Sumatra Indonesia. Journal of Wetlands Environmental Managements, 6(1), 12-26. https://dx.doi.org/10.20527/jwem.v5i2.108

Junedi, H., Armanto, M. E., Bernas, S. M., \& Imanudin, M. S. (2017). Changes to some physical properties due to conversion of secondary forest of peat into oil palm plantation. Sriwijaya Journal of Environment, 2(3), 76-80. https://dx.doi: 10.22135/sje.2017.2.3.76-80

Limba, R. S., Lio, A., \& Husain, Y. S. (2017). Shifting cultivation system of indigenous moronene as forest conservation on local wisdom principles in Indonesia. Journal of Sustainable Development, 10(4), 121-129. https://doi.org/10.5539/jsd.v10n4p121

Lu, S. M. (2017). Soil and forest: The key factors for human survival. Journal of Sustainable Development, 10(3), 105-119. https://doi.org/10.5539/jsd.v10n3p105

Mugisha, J., Mwadime, R., Sebatta, C., Gensi, R., \& Obaa, B. (2017). Factors enhancing household nutrition outcomes in potato value chain in South-Western Uganda. Journal of Sustainable Development, 10(3), 215-230. https://doi.org/10.5539/jsd.v10n3p215

Ningsih, R., Sjarkowi, F., Sufri, M., Adriani, D., \& Wildayana, E. (2017). Analysis of Remoteness Effect of Indigenous Coconut (Cocosnucifera L.) Commodity on Farmers Profit at Tidal Lowland Area of Jambi $\begin{array}{lllll}\text { Province-Indonesia. Sriwijaya Journal of } & \text { Environment, } & \text { 2(3), }\end{array}$ https://dx.doi:10.22135/sje.2017.2.3.88-92

Pangerungan, Y., Syahlani, S. P., \& Haryadi, F. T. (2017). An evaluation of the sustainable community development of pig farming, under the serasah system, in Wonosobo Regency, Indonesia. Journal of Sustainable Development, 10(3), 231-242. https://doi.org/10.5539/jsd.v10n3p231

Sarno, Suwignyo, R. A., Dahlan, Z., Munandar, Ridho, M. R., Aminasih, N., Harmida, Armanto, M. E., \& Wildayana, E. (2017). The phenology of Sonneratia alba J. Smith in Berbak and Sembilang National Park, South Sumatra, Indonesia. Biodiversitas, 18(3), 909-915. Doi: 10.13057/biodiv/d180307

Udoh, E. J., Akpan, S. B., \& Uko, E. F. (2017). Assessment of sustainable livelihood assets of farming households in Akwa Ibom State, Nigeria. Journal of Sustainable Development, 10(4), 83-96. https://doi.org/10.5539/jsd.v10n4p83

Wildayana, E. (2017). Challenging constraints of livelihoods for farmers on the South Sumatra Peatlands, Indonesia. Bulgarian Journal of Agricultural Science, 23(6), 894-905. Retrieved from http://www.agrojournal.org

Wildayana, E. (2018). Dynamics of landuse changes and general perception of farmers on South Sumatra Wetlands. Bulgarian Journal of Agricultural Science, 24(2), 180-188. Retrieved from http://www.agrojournal.org

Wildayana, E., \& Armanto, M. E. (2018). Utilizing non-timber extraction of swamp forests over time for rural livelihoods. Journal of Sustainable Development, 11(2), 52-62. https://doi.org/10.5539/jsd.v11n2p52

Wildayana, E., Adriani, D., \& Armanto, M. E. (2017). Livelihoods, household income and indigenous technology in South Sumatra Wetlands. Sriwijaya Journal of Environment, 2(1), 23-28. http://dx.doi.org/10.22135/sje.2017.2.1.23-28

Wildayana, E., Busri, A. B., \& Armanto, M. E. (2016a). Value changes of lebak swamp land over time in Jakabaring South Sumatra. Journal of Wetlands Environmental Managements, 4(1), 46-54. http://dx.doi.org/10.20527/jwem.04.01.06

Wildayana, E., Imanudin, M. S., Junedi, H., Zuhdi, M., \& Armanto, M, E. (2016b). Parameters affecting household income diversity of farmer's tribes in South Sumatra Tidal Wetland. Sriwijaya Journal of Environment, 1(3), 47-52. http://dx.doi.org/10.22135/sje.2016.1.3.47-52

Yosada, K. R., Djatmika, E. T., Soetjipto, B. E., \& Wahyono, H. (2017). Farmers' household empowerment in Entikong, West Kalimantan, Indonesia. Journal of Sustainable Development, 10(6), 254-260. https://doi.org/10.5539/jsd.v10n6p254

Zahri, I., Sabaruddin, Harun, M. U., Adriani, D., \& Wildayana, E. (2018). Comparing rice farming appearance of 
different agroecosystem in South Sumatra, Indonesia. Bulgarian Journal of Agricultural Science, 24(4), 189-198. Retrieved from http: //www.agrojournal.org

\section{Copyrights}

Copyright for this article is retained by the author(s), with first publication rights granted to the journal.

This is an open-access article distributed under the terms and conditions of the Creative Commons Attribution license (http://creativecommons.org/licenses/by/4.0/). 